Vladan Kuzmanovic

Associate Professor

University of Belgrade

Faculty of Civil Engineering

Ljubodrag Savic

Professor

University of Belgrade

Faculty of Civil Engineering

Nikola Mladenovic

Professor

University of Belgrade

Faculty of Mechanical Engineering

\section{Thermal-Stress Behaviour of RCC Gravity Dams}

Roller Compacted Concrete (RCC) is a special concrete mixture with low cement content, frequently used for concrete gravity dams. This paper deals with the $3 D$ finite element model for unsteady phased thermal-stress analysis of RCC dams. Model calibration and verification has been done, based on the in-situ measurements of the Platanovryssi dam. The study has been done using the actual dam shape, RCC time schedule, and material properties. The results prove that the recommended $3 D$ model enables a reliable thermal-stress prediction and transversal joint distance computation for an RCC gravity dam.

Keywords: RCC dam, thermal analysis, thermal-stress, transversal joint distance.

\section{INTRODUCTION}

Roller Compacted Concrete (RCC) is a special concrete mixture with low cement content, frequently used for concrete gravity dams. To reduce the thermal cracking, RCC dams are usually cut by transverse contraction joints into monoliths. The number and position of the joints should be determined based on the thermal-stress computations. The numerical model should consist of: (a) definition of the thermal and mechanical RCC properties, (b) computation of the temporal evolution of the thermal field, and (c) thermal-stress computation. Up to date models do not simulate accurately the longterm RCC behaviour ([1], [2]), due to simplifications. This research presents one of the first attempts to faithfully predict the RCC dams contraction joint distance, and to estimate it's influence on the thermal stress field. The developed model takes into account: the actual shape of the dam, different types of concrete, actual initial and boundary conditions, thermal and mechanical properties of RCC and construction technology, [3]. Calibration and verification of the thermal model are based on the in-situ temperature measurements of the Platanovryssi dam, [4].

\section{THEORETICAL BACKGROUND}

The change of temperature (T) of a nonhomogeneous, isotropic body in time $(\mathrm{t})$, due to the hydration heat, is described by the Fourier heat conductivity equation. If the thermal conductivity is independent of space and temperature:

$$
\frac{\partial \mathrm{T}}{\partial \mathrm{t}}=\alpha_{\mathrm{T}} \cdot \Delta \mathrm{T}+\frac{q}{\mathrm{c} \cdot \rho},
$$

where: $\alpha_{\mathrm{T}}=\lambda /(\mathrm{c} \cdot \rho)-$ diffusivity, $\mathrm{c}-$ specific heat, $\rho-$

Received: July 2013, Accepted: December 2013

Correspondence to: Nikola Mladenovic

Faculty of Mechanical Engineering,

Kraljice Marije 16, 11120 Belgrade 35, Serbia

E-mail: nmladenovic@mas.bg.ac.rs

doi:10.5937/fmet1501030K

(C) Faculty of Mechanical Engineering, Belgrade. All rights reserved density, $\lambda-$ thermal conductivity, $\Delta \mathrm{T}=\operatorname{div}(\operatorname{grad} \mathrm{T})-$ Laplace temperature operator and $\mathrm{q}-$ thermal source $=$ $c \cdot \rho \cdot \frac{\partial \mathrm{T}_{\mathrm{ad}}}{\partial t}$, defined as a function of adiabatic temperature rise $\left(\mathrm{T}_{\mathrm{ad}}\right)$.

RCC thermal behaviour greatly depends on the hydration processes of cementitious materials (cement and fly-ash). Hence, an adequate hydration-heat model must be defined and used. The presented model uses the degree of reaction method, [5]. The degree of reaction, $\mathrm{r}(\mathrm{t})$, ranges from 0 to 1 , and is defined as a ratio between the heat released from the beginning of the reaction to the specified time, $t$, and the total amount of heat released due to the hydration. The amount of released heat is a function of a temperature time-history, and is mostly influenced by the temperature dependant increment of hydration heat, $\mathrm{q}_{\mathrm{T}}(\mathrm{T})$, defined as:

$$
\mathrm{q}_{\mathrm{T}}(\mathrm{T})=e^{\frac{-C_{A}(r, T)}{T+273}},
$$

where $\mathrm{C}_{\mathrm{A}}(\mathrm{r}, \mathrm{T})$ - Arhenius constant.

The differential FEM matrix formulation of thermalstress analysis yields [5]:

$$
\mathrm{C} \cdot \dot{\mathrm{u}}+\mathrm{K} \cdot \mathrm{u}+\mathrm{f}=0
$$

where: C-damping matrix, $\dot{\mathbf{u}}$-vector of unknown velocities, $\mathbf{K}$-stiffness matrix, $\mathbf{u}$-vector of unknown nodal displacements, and $\mathbf{f}-$-vector of nodal loads.

If conductivity, specific heat, and/or boundary conditions are temperature dependant, the problem becomes nonlinear, and the equation system (3) has to be solved iteratively. The dam body and foundation rock have been discretized by solid brick twenty-node isoparametric elements. The element is based on the quadratic interpolation and Gaussian integration.

In the phased thermal-stress analysis, used in this research, computational results from the previous construction phase are stored, and used as an initial condition for the following phase. From one phase to another, new parts of the model may show up (and some become inactive), therefore the active elements have to 
be defined at the beginning of the each phase. Within the each phase, the computation is performed in a given number of time steps, defined according to the observed concrete placement schedule, [6-8].

\section{NUMERICAL MODEL}

The numerical model is developed using the Finite Element Method based on the Diana package, [5]. The FEM formulation of the heat conductivity equation (1) yields:

$$
\mathbf{K} \cdot \mathbf{T}+\mathbf{C} \cdot \dot{\mathbf{T}}=\mathbf{Q},
$$

where: $\mathbf{K}$ - the thermal conductivity matrix, $\mathbf{C}-$ the capacity matrix, $\mathbf{Q}$ - the nodal discharge. Since a nonlinear thermal problem is considered (properties and/or the boundary conditions depend on time), the incremental-iterative method is used for solving eq. (4).

The 3D model is applied to the non-overflow monolith, of the Platanovryssi dam. This dam is the highest to date RCC dam in Europe, $95 \mathrm{~m}$ high, with the crest length and width of $280 \mathrm{~m}$ and $7 \mathrm{~m}$. The dam is built using $30 \mathrm{~cm}$ thick layers, and is divided into 13 monoliths by vertical contraction joints.

The initial conditions are defined by the temperatures at the finite element nodes, obtained from the observed mixture temperatures of each layer. The temperature boundary conditions include a constant temperature at the outside rock and the time variable temperature at the faces, galleries, or at the current top layer (during the construction), defined according to the available in-situ measurements [4]. The displacement boundary conditions are prescribed at the outer surfaces of the foundation rock.

\section{RESULTS OF THERMAL FIELD COMPUTATION}

The time evolution of the 3D thermal field of the representative dam monolith is presented in Fig. 1 and Fig. 2. During the initial phase of the construction, a "hot core" has formed some $10 \mathrm{~m}$ above the foundation line. The core has been gradually cooling for the following four months. By the summer, the air temperature rises, causing formation of another hot core (Fig. 1). After the completion of the dam, and the filling of the reservoir, only one hot core remains, at the centre of the dam (Fig. 2).

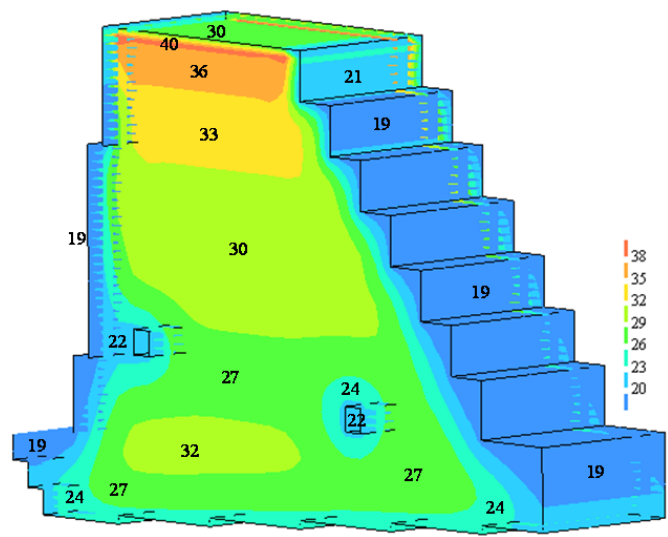

Figure 1. 3D Temperature field on 1.6.1996

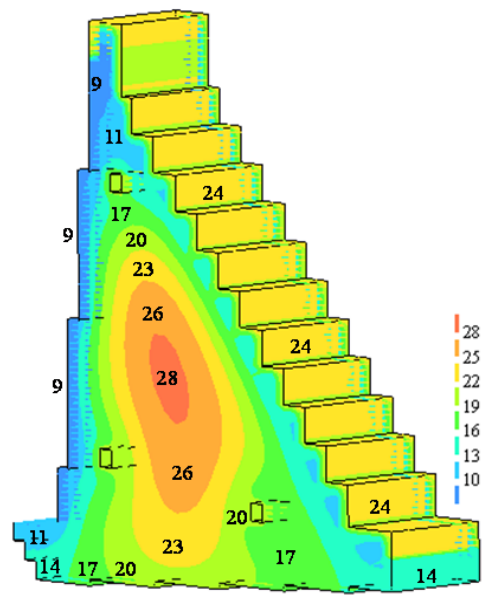

Figure 2. 3D Temperature field on 15.6.1999

\section{RESULTS OF THERMAL-STRESS COMPUTATION}

The normal stresses in the dam-axes direction, $\sigma_{\mathrm{z}}$, are considered. The stresses are primarily influenced by the temperature field, and to a less degree by the dead load, while the effect of other loads may be neglected, [8]. The tensile stresses are accepted to be positive, and the compressive stresses are negative.

Thermal-stress computation is performed for the 3 values of the monolith length: $16 \mathrm{~m}, 20 \mathrm{~m}$, and $24 \mathrm{~m}$. In this section, only the results for the $16 \mathrm{~m}$ monolith are presented.

At the Fig. 3, the stresses in the rock are equal to zero. Tensile stresses in the lower zone of the dam are less than 1.20 $\mathrm{MPa}$ (since the concrete have already reached its maximal temperature, and began to cool), while at the upper zone compressive stresses occur (as the temperature is still rising and the concrete is expanding). The stress concentration along the horizontal joints, between the successive layers are the consequence of the difference between the stiffness of the layers.

At the Fig. 4, 166 days after the commencement of concreting, the dam was $46 \mathrm{~m}$ high, with $153 \mathrm{RCC}$ layers placed. The maximum tensile stress of $1.62 \mathrm{MPa}$ occurred bellow the ground level, at the vicinity of the upstream and downstream faces. The maximum compressive stress was -1.94 Mpa.

One can observe that for all the elements, compressive stresses develop during the first 5 to 10 days after the placing, as a consequence of the hydration heat.

The concrete tends to expand, and due to the restricted strains, the compressive stresses issue. When the concrete begin to cool, the shrinkage follows, and the tensile stresses result. The maximum tensile stresses depend on the temperature gradient, and the current stiffness of RCC.

The element 702 is within a massive structure, but relatively close to the upstream face, which influences the thermal-stress behaviour. After the initial compression, and tension phase, the stresses are mildly influenced by temperature boundary conditions. The element 2743 is strongly influenced by the downstream temperature boundary condition. Intensive insulation causes high amplitude oscillations, together with the 
high tensile stresses (up to $0.8 \mathrm{MPa}$ ). The stress behaviour of element 5836 at the dam crest is governed by both, upstream and downstream boundary condition, with the less significant effect of insulation.

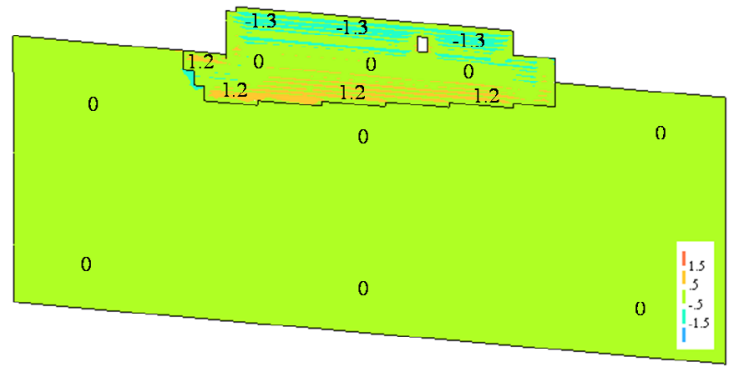

Figure 3. Middle plane stress-field, 9.1.1996

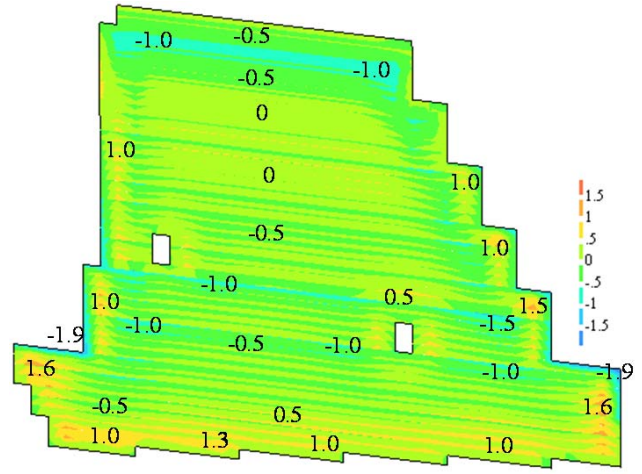

Figure 4. Middle plane stress-field, 1.4.1996

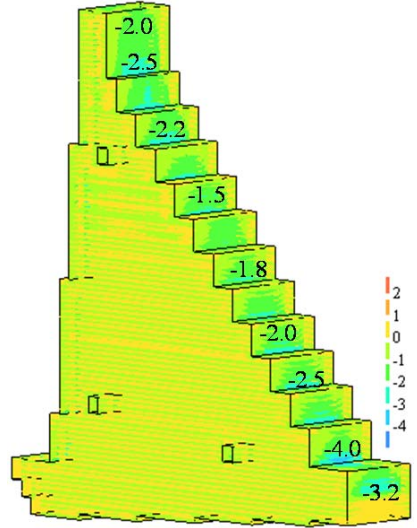

Figure 5. Surfaces Stress-field 1.9.1997

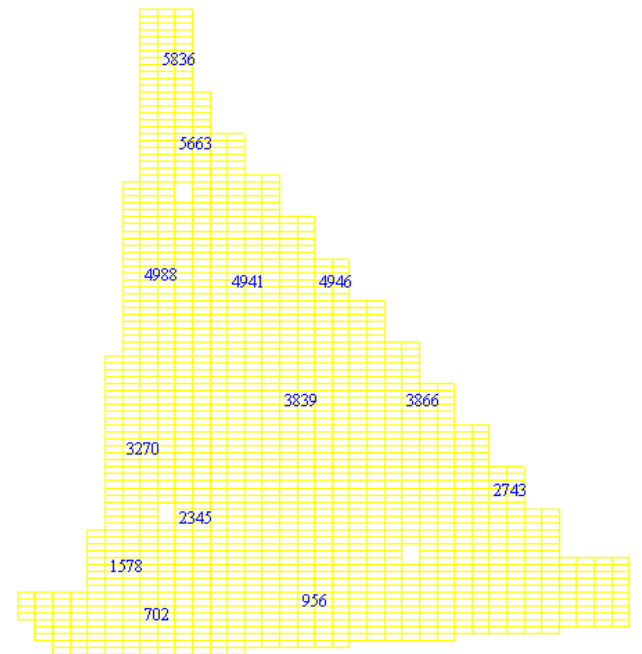

Figure 6. Characteristic elements at the middle plane

\section{TRANSVERSAL JOINT DISTANCE}

The influence of temperature on the transversal joint distance is analysed, based on the results of the presented model, and the observed data. The length of the monolith of $16 \mathrm{~m}, 20 \mathrm{~m}$, and $24 \mathrm{~m}$ is considered (models 3DL16, 3DL20, and 3DL24, respectively). At Fig. 8, the thermal stress evolution of the characteristic element in the middle plain is presented. One can observe that the stresses at the upstream face (the element 4988) follow the seasonal temperature oscillations. After the reservoir impounding, the stress oscillations dampen, due to the constant water temperature. The mean square deviation between 3DL24 and 3DL20 is negligible (0.07 MPa), comparing to the deviation of $0.16 \mathrm{MPa}$, between 3DL20 and 3DL1

Based on the maximum tensile stresses, their mean square deviation at characteristic elements, and the stress-field time evolution, it follows that the thermal stresses for RCC gravity dams depend on the monolith length. For the considered Platanovryssi dam, the mean square deviation of thermal stresses, between 3DL24 and 3DL20 is $0.11 \mathrm{MPa}$, and between 3DL20 and 3DL16 is $0.16 \mathrm{MPa}$. Increasing the monolith length from $20 \mathrm{~m}$ to $24 \mathrm{~m}$, rises the maximal thermal stresses for about $0.33 \mathrm{MPa}(12.2 \%)$. Reducing the monolith length from $20 \mathrm{~m}$ to $16 \mathrm{~m}$, decrease the maximal stresses for about $0.20 \mathrm{MPa}(7.4 \%)$.

Having in mind the computed maximal tensile stresses (depending on the monolith length), and the observed RCC tensile strength of $2.70 \mathrm{MPa}$ [4], one may conclude that the maximal monolith length for the Platanovryssi dam should be $20 \mathrm{~m}$. Bearing in mind that the constructed length of the particular monolith is 22 $\mathrm{m}$, and with some cracking and leakage issuing at the downstream face (which implies exceeding of the tensile strength), it may be concluded that a somewhat shorter monolith should have been used.

\section{CONCLUSIONS}

- For the first time a comprehensive 3D numerical model for the phased thermal-stress analysis of the massive concrete structures has been developed, providing for a reliable evaluation of the transversal joint distance.

- Having in mind the maximum tensile stresses, their mean square deviation at characteristic elements, and the stress-field time evolution, it follows that the thermal stresses for RCC gravity dams depend on the transversal joint distance.

- The most important indicator of the thermal behaviour of RCC gravity dams, are the stresses in the direction of the dam axes.

- The shape of the diagram of the normal stresses time evolution, depends on the position in the middle plane, but it is almost independent on the monolith length

- It is not possible to formulate the universal suggestions for all RCC dams. Therefore, for each particular dam, the thermal-stress analyses should 
be performed to obtain the best estimate of the transversal joint distance.

\section{ACKNOWLEDGEMENT}

This work was supported by the Ministry of Education and Science of the Republic of Serbia under project no. TR 37009 "Monitoring and Modeling of Rivers and Reservoirs - Physical, Chemical, Biological and Morphodynamic Parameters".

\section{REFERENCES}

[1] Crichton, A., Benzenati, I., Qiu, T. and Williams, J.: Kinta RCC Dam - Are Oversimplified Thermal Structural Analysis Valid?, Proceedings of Australian National Committee on Large Dams Conference, 1999, Jindabyne, pp. 446-457.

[2] Aniskin, N.A.: Temperature regime of a gravity dam from rolled concrete, Power Technology and Engineering, Vol. 40, pp. 23-27, 2006.

[3] M. Dunstan \& Associates Consulting Engineers: Platanovryssi Hydroelectric Project, Review of the Properties of the Concretes in Platanovryssi Dam, Devon, England, 1996.

[4] Public Power Corporation: Platanovryssi Hydroelectric Project, Measurement Results, Athens, Greece, 2004.

[5] TNO Building and Construction Research: Diana User's Manual, Delft, The Netherlands, 2002.

[6] Kuzmanović, V.: Thermal-stress analysis of roller compacted concrete dams, $\mathrm{PhD}$ thesis, Department of Civil Engineering, The University of Belgrade, Serbia, 2007, (in Serbian).
[7] Kuzmanovic, V., Savic, Lj. and Stefanakos, J.: Long-term thermal analysis of RCC dams using 2D and 3D models, Canadian Journal of Civil Engineering, Vol. 37, pp. 600-610, 2010.

[8] Kuzmanovic, V., Savic, Lj. and Mladenovic, N.: Computation of Thermal-Stresses and Contraction Joint Distance of RCC Dams, Journal of Thermal Stresses, Vol. 36, pp. 112-134, 2013.

\section{ТЕРМИЧКО НАПОНСКО СТАЫЕ ГРАВИТАЦИОНИХ БРАНА ОД ВАљАНОГ БЕТОНА}

\section{Владан Кузмановић, Љубодраг Савић, Никола Младеновић}

Бетон збијен ваљањем (,ваљани бетон“ или „RCC“ Roller Compacted Concrete) је врста бетона са ниским садржајем цемента која се често користи код бетонских гравитационих брана. У раду је разматран просторни модел за неустаљену фазну термичконапонску анализу брана од ваљаног бетона. Калибрација и верификација модела уређени су на основу теренских мерења на брани Платановриси. Истраживање је урађено узимајући у обзир стварну геометрију бране, динамику уградње RCC-a и стварне особине материјала. Резултати прорачуна показују да развијени 3D модел омогућава поуздано предвиђање термичких напона и одређивање растојања између разделница код гравитационих RCC брана.

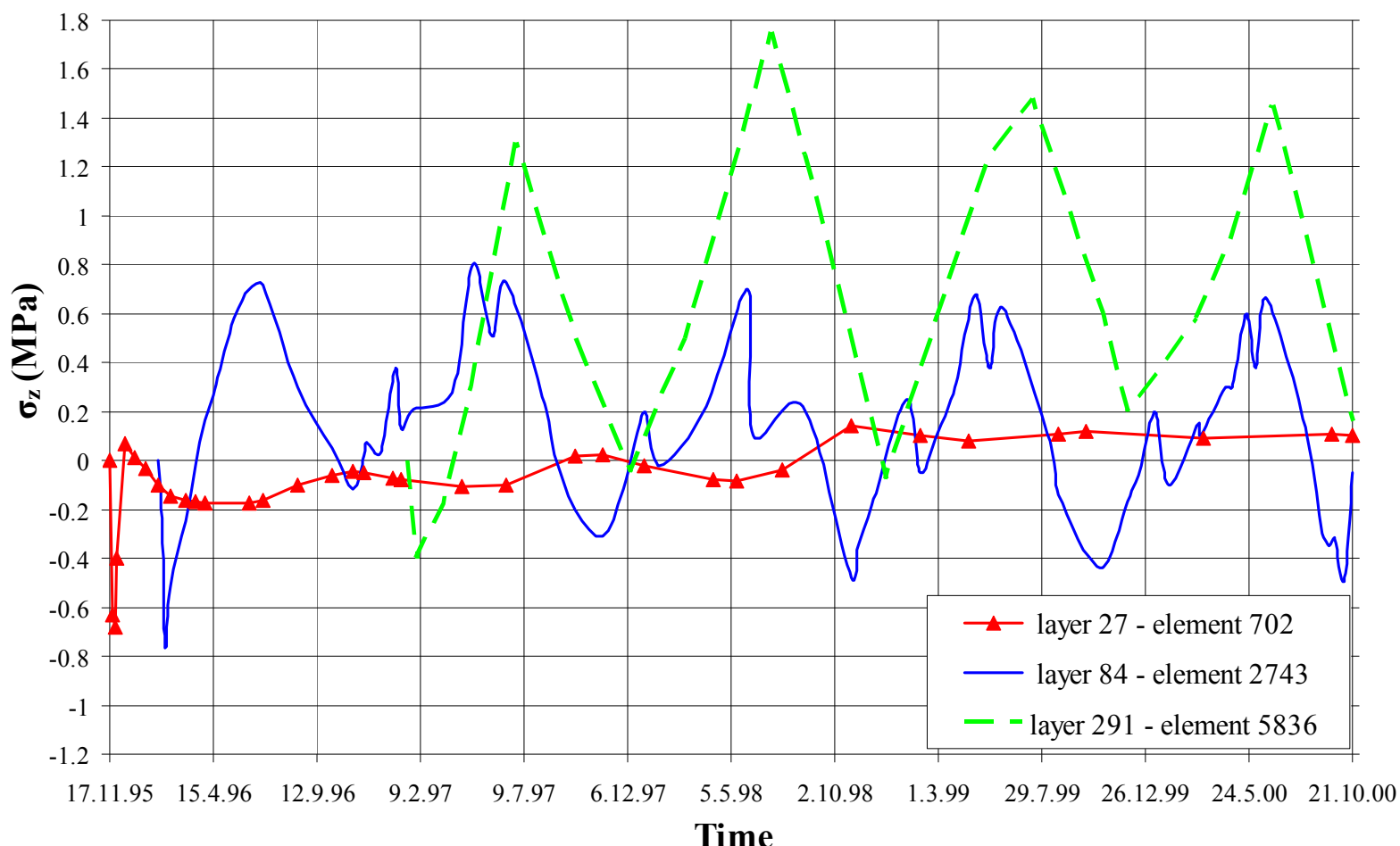

Figure 7. Stress evolution at the elements 702, 2743, and 5836 


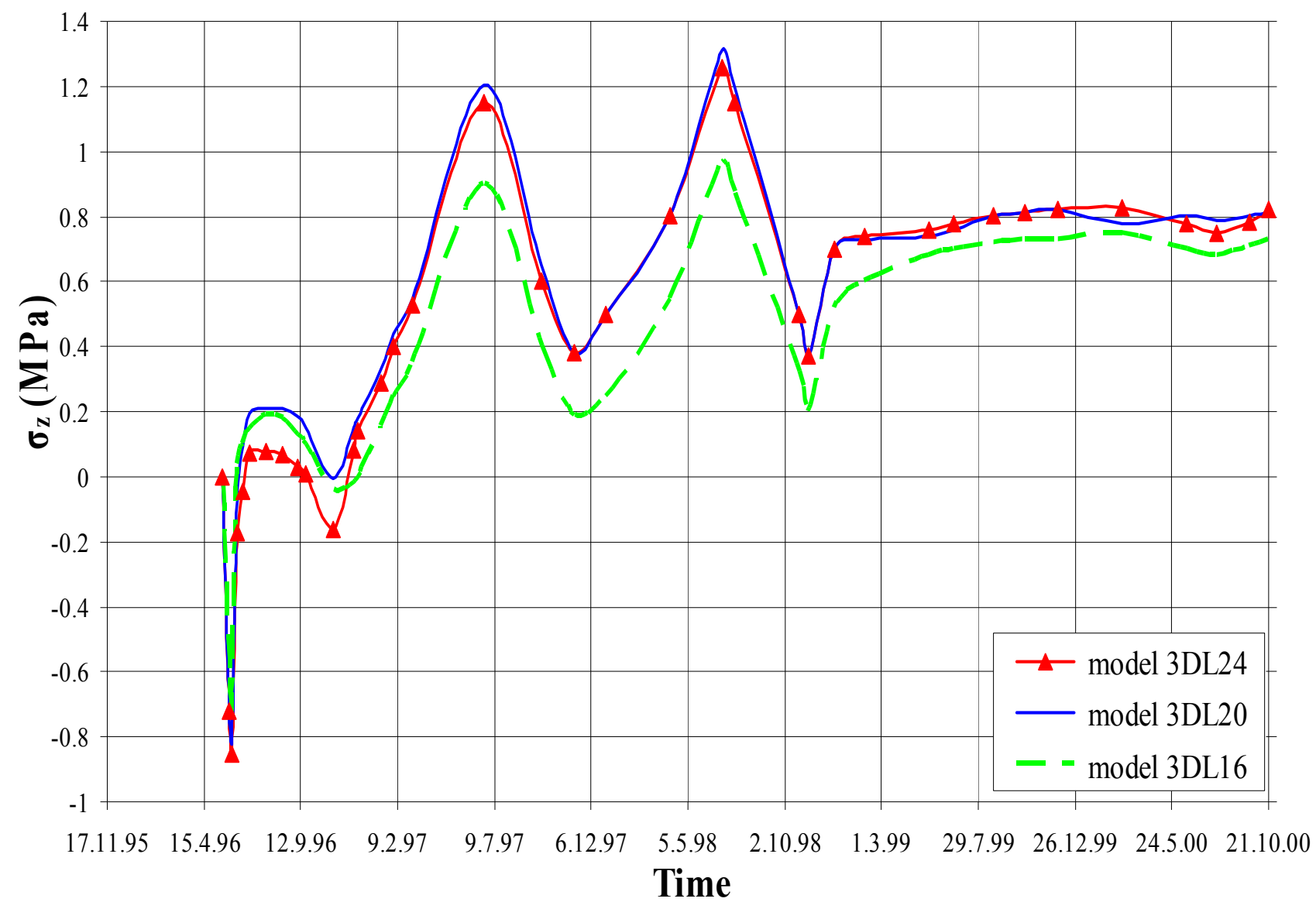

Figure 8. Stresses at element 4988 (layer No. 187), depending on the monolith length 